\title{
Energy and Economic Analysis of the Wind Turbine Plant's Draft for the Aksaray City
}

\author{
Tolga Taner ${ }^{1, *}$, Oğuz Kürşat Demirci ${ }^{2}$ \\ ${ }^{1}$ Department of Motor Vehicles and Transportation Technology, Aksaray University, Aksaray, Turkey \\ ${ }^{2}$ Department of Motor Vehicles and Transportation Technology, Erzincan University, Erzincan, Turkey \\ *Corresponding author: tolgataner@aksaray.edu.tr
}

Received June 06, 2014; Revised June 18, 2014; Accepted June 22, 2014

\begin{abstract}
This study presents energy and economic analysis of the wind turbine plant's draft for the Aksaray city. Fossil fuels are used for energy production that is giving the environmental damage and increasing the global warming. The countries utilize a renewable energy for decreasing the global warming's impacts. The wind energy is the one of the important renewable energy. In this study, drafting 1 [MW] of the wind turbine plant was calculated energy and economic analysis for the Aksaray city. When $1[\mathrm{MW}]$ of the wind turbine plant is set up, it was calculated production of energy quantity that was found 2628000 [kWh]. Cost of the total investment was obtained 1 698312 [\$] and cost of the unit electric energy was found 0.052 [\$/kWh]. The wind power plant's construction was calculated step by step that these values were found in with escalation way and without escalation way. According to these results, the units of the investment's cost, unit of the operation's cost, unit of the maintenance's cost were calculated for economic analysis. In conclusion, energy and economic analysis of the wind turbine plant's draft is the first academic study for the Aksaray city. According to the literature, building the wind energy plant between Ortaköy village and Ağaçören village can be suitable for the Aksaray city.
\end{abstract}

Keywords: economy, energy, renewable energy, wind energy, escalation

Cite This Article: Tolga Taner, and Oğuz Kürşat Demirci, "Energy and Economic Analysis of the Wind Turbine Plant's Draft for the Aksaray City.” Applied Ecology and Environmental Sciences, vol. 2, no. 3 (2014): 82-85. doi: 10.12691/aees-2-3-2.

\section{Introduction}

Wind energy is becoming one of the important renewable sources of energy in the world that is a clean energy. The world energy crises can be solved in the future by the other renewable sources of energy, such as solar energy. Wind energy conversion systems (WECS) are used the classification of most common electric generator types in megawatt range. WECS is not only to capture the maximum power from the wind but also to improve the quality of power [1]. Wind power plants are been developed around the world. However, there are some problems that should be considered in planning wind's resources. One of the important problem is giving impact to the farms because of wind plant's area [2]. So the wind plants can be set to the barren lands that can be solved this problem.

In our modern life increases demand of energy last decades. Most of the current energy sources are giving exhaust to the air and waste to the ground. Moreover, a coal and fuel produces high level air pollution that the combustion process of the current energy sources causes global warming. By the way, a renewable energy has been used in recent days and in the future. Thus, where the wind is an efficient place that wind power plant is established [3,4].
Wind energy has an important among the renewable energy sources. The wind's kinetic energy has been be converted to electricity energy. Wind turbines are the main component of Wind Energy Centrals that are the machines which convert the kinetic energy of moving air to mechanic energy and then to electricity energy $[5,6]$.

\section{Information of Aksaray City and Location}

Aksaray locates in the middle Kizılırmak area of the central Anatolia reagion which has north and south Anatolian mountain for each other. Its mathematic location is 37-38 Norht parallels and 33-35 East meridians. It surrounded with Nevşehir (East), Niğde (Southern east), Konya (West), Ankara (North) and Kırşehir (Northern east).It has got a large $7997 \mathrm{~km}^{2}$ floor space [7].

Lake Tuz catchment is mostly under the effect of North, Northern east and East winds mostly. According to 34year observations of Aksaray Meteorology Station; the most blowing sides around Aksaray is by turn, eastnortheast (6464), north-east (4259), east (1197), westnorthwest (2870), north-northeast (1754) [8].

In Figure 1, the average wind speed in North areas is seen as $7 \mathrm{~m} / \mathrm{s}, 3.5 \mathrm{~m} / \mathrm{s}$ in middle areas and in the South areas it is change as $5-6 \mathrm{~m} / \mathrm{s}$. The wind speed must be over than $7 \mathrm{~m} / \mathrm{s}$ for an economical investment of WEC. It has 
been understood that the most suitable place WEC is for building in the North areas of Aksaray. The convenient field is approximately $650 \mathrm{~km}^{2}$ for building WEC in Aksaray. The total floor space of Aksaray is $7626 \mathrm{~km}^{2}$ so the suitable field is $8.53 \%$ of total floor space.

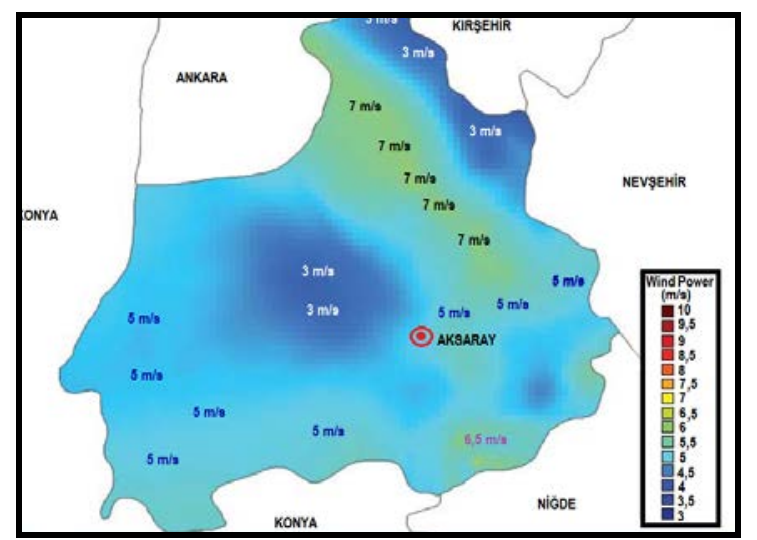

Figure 1.Wind energy potential of Aksaray city

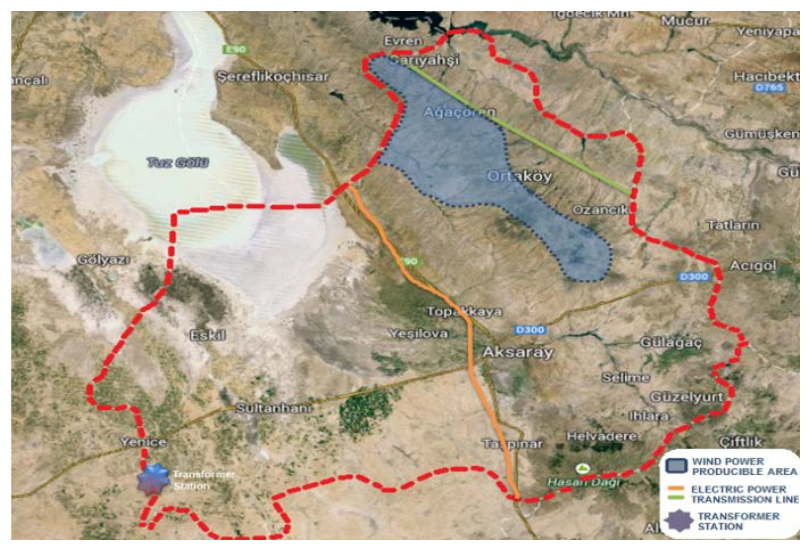

Figure 2. Suitable areas for producible wind energy and transmission lines for Aksaray

Figure 2, the most suitable WEC building area and energy transmission lines have been seen that energy transmission lines has been an advantage for WEC building. If the transmission lines are near, cost of WEC can decrease.

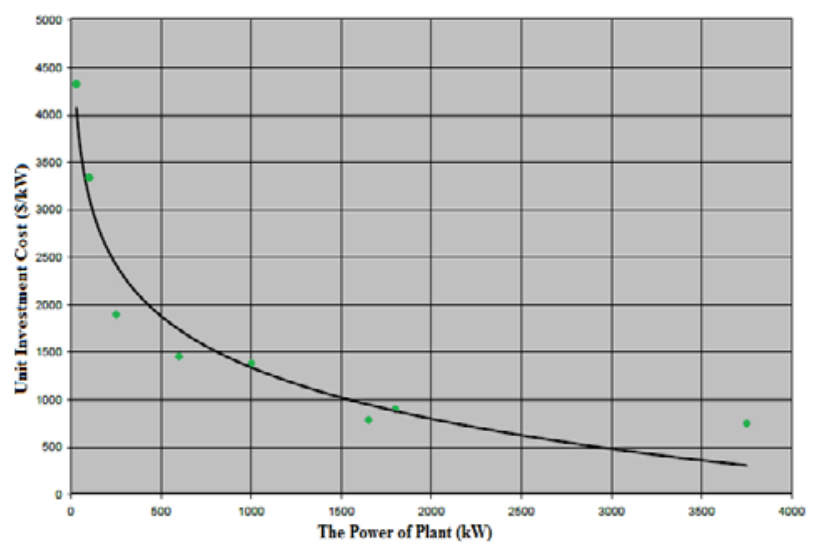

Figure 3.Wind energy plant unit price graph for plant [10]

Figure 3, When the power of plant increases, unit investment cost decreases. While power increases, investment cost and unit energy cost decrease together unit price. Unit price is determined as Cs is a 1400 [\$/kW] at Wind Central which 1 [MW] power.

\section{Calculation of Unit of Electricity Energy's Cost for 1 MW Power Plant and Results}

Unit of electricity energy can be calculated for $1 \mathrm{MW}$ power plant and results are given in this section. Energy plant's operating life was taken 25 years, specially. Before calculations, some assumptions were made as they are shown;

$$
\begin{aligned}
& \mathrm{i}=0.04 \text { (Interest Rate) } \\
& \mathrm{nH}=25 \text { years (Energy plant's operating life) } \\
& \mathrm{Lf}=0.3 \text { (Load Factor) } \\
& \mathrm{Ne}=1[\mathrm{MW}]=1000[\mathrm{~kW}] \text { (Installed Power) } \\
& \mathrm{Cs}=1400[\$ / \mathrm{kW}] \text { (unit investment cost was } \\
& \text { Fig. } 3 \text { ) } \\
& \mathrm{e}=0.06 \text { (Escalation Rate) } \\
& \text { ti }=3 \text { years (WEC Building Time). }
\end{aligned}
$$$$
\mathrm{nH}=25 \text { years (Energy plant's operating life) }
$$$$
\mathrm{Cs}=1400[\$ / \mathrm{kW}] \text { (unit investment cost was found from }
$$

\subsection{Investment Cost $\left(I_{d}\right)$}

Investment cost was calculated from unit investment cost value. This formulas is shown as;

$$
\mathrm{I}_{\mathrm{d}}=\mathrm{C}_{\mathrm{s}} \text {. Ne }
$$

$$
I_{d}=1400.1000=1400000[\$] \text {. }
$$

\subsection{During Building the Load Of Escalation $\left(\mathbf{Y e}_{\mathrm{t}}\right)$}

Escalation is the process of increasing, attained from the purport of an escalator that load of escalation is an increase in the price of goods. It is determined total spending rate while creating cost plan, as $30 \%$ for first year, for second year $50 \%$, for third year $20 \%$.

$$
\mathrm{Ye}_{\mathrm{t}}=\mathrm{Y}_{\mathrm{t}}(1+\mathrm{e})^{\mathrm{t}}
$$

For $2014 \mathrm{Y}_{\mathrm{t}}=1400000 \times 0.3=420000[\$]$

For $2015 \mathrm{Y}_{\mathrm{t}}=1400000 \times 0,5=700000[\$]$

For $2016 \mathrm{Y}_{\mathrm{t}}=1400000 \times 0,2=280000$ [\$].

This values are cost plan except 3 yearly escalation calculate. If we add escalation to this calculation;

For $2014 \mathrm{Ye}_{\mathrm{t}}=420000 \times(1+0.06)^{1}=445200$ [\$]

For $2015 \mathrm{Ye}_{\mathrm{t}}=700000 \times(1+0.06)^{2}=786520$ [\$]

For $2016 \mathrm{Ye}_{\mathrm{t}}=280000 \times(1+0.06)^{3}=333484$ [\$].

\subsection{Cost Plan with Escalation}

Cost plan with escalation is calculated above years of the load escalations.

$$
\mathrm{Ye}_{\mathrm{t}}(\text { Total })=1565204[\$]
$$

\subsection{Cost Plan without Escalation}

Cost plan without escalation is calculated above years of the load without escalations.

$$
\mathrm{Y}_{\mathrm{t}}(\text { Total })=1400000[\$]
$$

\subsection{Interest Calculation (During Build)}

Interest calculation is estimated this formulas as is shown;

$$
T_{t}=Y e_{t}\left[(1+i)^{s-t_{i}}\right]
$$


$\mathrm{s}=$ Remaining build time for finish of build. (year) Interest calculations are estimated in three-years;

For $2014 \mathrm{~T}_{\mathrm{t}_{1}}=445200 \mathrm{x}(1+0.04)^{3}=500789.45[\$]$

For $2015 \mathrm{~T}_{\mathrm{t}_{2}}=786520 \mathrm{x}(1+0.04)^{2}=850700.03[\$]$

For $2016 \mathrm{~T}_{\mathrm{t}_{3}}=333484 \mathrm{x}(1+0.04)^{1}=346823.36[\$]$.

\subsection{Total Investment Cost (YM)}

When total interest during build time to cost plan too; total investment cost appears.

$$
\begin{gathered}
\mathrm{Y}_{\mathrm{M}}=\mathrm{T}_{t_{1}}+\mathrm{T}_{t_{2}}+\mathrm{T}_{t_{3}} \\
\mathrm{Y}_{\mathrm{M}}=500789.45+850700.03+346823.36 \\
\mathrm{Y}_{\mathrm{M}}=1698312.842[\$]
\end{gathered}
$$

\subsection{Yearly Fixed Capital Cost $\left(C_{k}\right)$}

Yearly fixed capital cost is calculated this formulas as is shown;

$$
\begin{aligned}
& C_{k}=Y_{M}\left[\frac{i(1+i)^{n_{H}}}{(1+i)^{n_{H}}-1}\right] \\
& C_{k}=1698312.842\left[\frac{0.04(1+0.04)^{25}}{(1+0.04)^{25}-1}\right] \\
& C_{k}=1698312.842\left[\frac{0.10663}{1.6658}\right] . \\
& \text { It was calculated as; } \\
& C_{k} \cong 108708.82[\$] .
\end{aligned}
$$

\subsection{Yearly Produced Energy Amount (E)}

Yearly produced energy amount is calculated this formulas as is shown;

$$
E=24.365 \times N e \times L_{f}
$$

It was calculated as;

$$
E=24.365 \times 1000 \times 0.30=2628000[\mathrm{kWh}] .
$$

\subsection{Unit Of Investment Cost $\left(\mathrm{YM}_{\mathrm{b}}\right)$}

Unit of investment cost is calculated this formulas as is shown;

$$
Y M_{b}=\frac{C_{k}}{E}
$$

It was calculated as;

$$
\begin{aligned}
Y M_{b} & =\frac{108708.82}{2628000} \\
Y M_{b} & =0.04136[\$ / \mathrm{kWh}]=41.36[\text { mills } / \mathrm{kWh}]
\end{aligned}
$$

\subsection{Unit Operating And Maintenance Cost $\left(\mathbf{Y} \mathbf{M}_{\mathbf{m}}\right)$}

Total yearly operating and care cost is $2 \%$ for starting.

$$
\mathrm{C}_{\mathrm{m}}=\mathrm{I}_{\mathrm{d}} \mathrm{x} 0.02
$$

$\mathrm{C}_{\mathrm{m}}=1400000 \times 0.02=28000[\$]$
Maintenance cost is calculated as;

$$
Y M_{m}=\frac{C_{m}}{E}
$$

It was calculated as;

$$
\begin{aligned}
Y M_{m} & =\frac{28000}{2628000} . \\
Y M_{m} & =0.01065[\$ / \mathrm{kWh}]=10.65[\text { mills } / \mathrm{kWh}] .
\end{aligned}
$$

\subsection{Unit of Electricity Energy Cost $\left(\mathrm{YM}_{\mathrm{e}}\right)$}

Unit of electricity energy is calculated this formulas as is shown;

$$
Y M_{e}=\frac{C_{k}+C_{m}}{E}=\frac{C_{t}}{E}
$$

It was calculated as;

$$
\begin{aligned}
Y M_{e} & =\frac{108708.82+28000}{2628000} \\
Y M_{e} & =0.052[\$ / k W h]=5.2[\operatorname{cent}(\$) / k W h] .
\end{aligned}
$$

\section{Conclusion and Discuss}

This study was shown that drafting 1 [MW] of the wind turbine plant for the Aksaray city was calculated energy and economic analysis. Firstly, during building the load of with and without escalation was calculated. It is determined total spending rate that is a scenario cost plan, as $30 \%$ for first year (a year 2014), for second year (a year 2015) $50 \%$, for third year (a year 2016) $20 \%$. Then total investment cost was found 1698312.842 [\$].Yearly produced energy amount's result was 2628000 [kWh]. Unit of investment cost's result was 0.04136 [\$ $\$ \mathrm{kWh}$ ]. Maintenance cost was calculated as a result was $0.01065[\$ \mathrm{kWh}]$. At the end of the unit of electricity energy was calculated as a final result was found 0.052 [\$/kWh].

Above these results are very available in literature. In conclusion, energy and economic analysis of the wind turbine plant's draft is the first academic study for the Aksaray city. It will be very efficiency energy for the Aksaray city. According to the literature, building the wind energy plant between Ortaköy village and Ağaçören village can be suitable for the Aksaray city.

\section{References}

[1] Gaillard, A.,Poure, P., and Saadate, S., "Reactive power compensation and active filtering capability of WECS with DFIG without any over-rating”, Wind Energ, 13 (7), 603-614. 2009.

[2] Ela, E., "Using economics to determine the efficient curtailment of wind energy", Technical Report NREL/TP-550 45071, National Renewable Energy Laboratory, Colorado, United States of America, 2009.

[3] Chen, Z. and Spooner, E., "Grid interface for renewable energy sources", 2nd International Power Electronics And Motion Control Conference (IPEMC'97), Hangzhou, China, 256-261, 1997.

[4] Tiwari, H. P. and Gidwani, L., "Wind energy-present scenario”,Electr. India Mag. 50 (4), 68-77, 2010.

[5] Özdamar, A., "Dünya ve Türkiye'de rüzgar enerjisinden yararlanılması üzerine bir araştırma", Journal of Engineering Sciences, 6 (2-3) 133-145, 2000. 
[6] http://www.eie.gov.tr/yenilenebilir/ruzgar-ruzgar_enerjisi.aspx, [Accessed,2013].

[7] http://www.aksaray.gov.tr/default_B0.aspx?content=1070, [Accessed,2013].

[8] ÇED Hizmetleri ve Çevre İzinleri İşleri Şube Müdürlüğü, “Aksaray ili çevre durum raporu 2011", Aksaray, Turkey, 2012.

[9] http://www.eie.gov.tr/yenilenebilir/ruzgar.aspx, [Accessed,2013].

[10] Kıncay, O.,Yumurtacı, Z. ve Bekiroğlu, N., "Rüzgar enerjisi”, Ders Notları, Yıldız Teknik Üniversitesi, İstanbul, Turkey, 2013.

[11] Machmouom, M., Boutoubat, M., Mokrani, L., "Power Quality Improvement Using Grid Side Converter of Wind Energy Conversion System”, Journal of Energy and Power Engineering 7, 752-759, 2013

[12] Lei, Y., Mullane, A., Lightbody, G., Yacamini, R., "Modeling of the wind turbine with a doubly fed induction generator for grid integration studies”, Energy Conversion, IEEE Transactions, 21 (1), 257-264, 2006.

[13] Chen, Z. and Spooner, E., "Grid power quality with variable speed wind turbines", Energy Conversion, IEEE Transactions, 16 (2), 148-153, 2001.

[14] Rodriguez, J., Fernandez, J. L. and Beato, D., "Incidence on power system dynamics of high penetration of fixed speed and doubly fed wind energy systems: Study of the Spanish case”, IEEE Trans. Power Syst., 17 (4), 1089-1095, 2002.

[15] Machmoum, M., Doeuff, R. L., and Sargos, F. M., "Steady state analysis of a doubly fed asynchrounous machine supplied by a current controlled cyclo converter in the rotor", Proc. Inst. Elect. Eng. B., 139 (2), 114-122, 1992.

[16] Carlin, P. W., Laxson, A. X., and Muljadi,E. B., "The History and State of the Art of Variable-Speed Wind Turbine Technology", National Renewable Energy Laboratory, 2001.

[17] Neris, A., Vovos, N., and Giannakopaulos, G., "A variable speed wind energy conversion scheme for connection to weak ac systems”, IEEE Trans. Energy Convers.,14 (1), 122-127, 1999.

[18] Feijo, A., Cidrs, J., and Carrillo, C., "Third order model for the doubly-fed induction machine", Elect. Power Syst. Res., 56, 121127, 2000.

[19] Hand, M. M. and Balas, M. J., "Systematic controller design methodology for variable-speed wind turbines", National Renewable Energy Laboratory, 2002.

[20] Miller, N. W., Sanchez-Gasca, J. J., and Price, W. W., "Dynamic modeling of GE 1.5 and 3.6 MW wind turbine generators for stability simulations", Proc. IEEE Power Engineering Society General Meeting, 3, 1977-1983, 2003. 